Yabin WANG

Jianmin ZHAO

Zhonghua CHENG

Zhiyuan YANG

\title{
INTEGRATED DECISION ON SPARE PARTS ORDERING AND EQUIPMENT MAINTENANCE UNDER CONDITION BASED MAINTENANCE STRATEGY
}

\section{ZINTEGROWANY SYSTEM DECYZYJNY DOTYCZĄCY ZAMAWIANIA CZĘŚCI ZAMIENNYCH I UTRZYMANIA RUCHU URZĄDZEŃ W RAMACH STRATEGII UTRZYMANIA ZALEŻNEJ OD BIEŻĄCEGO STANU TECHNICZNEGO}

\begin{abstract}
Aiming to optimize the equipment maintenance and the spare parts ordering management jointly, a comprehensive decision model under condition based maintenance (CBM) policy is presented for a single equipment system with continuous and random deterioration. In this model, the equipment deterioration is a continuous Gamma process under a continuous condition monitoring, and the spare parts inventory is controlled by spare parts support probability. Firstly, a spare part support probability model was developed to determine the optimal spare parts stock level $S$, which is set to meet the requirement of a predetermined stockout probability. Secondly, the equipment replacement and spare parts ordering decision is made to optimize the equipment replacement and spare parts ordering jointly, which is based on the equipment deterioration leveland total operating cost of the system. Thirdly, an integrated decision simulation model is presented for evaluating cost rate, availability and stockout probability. Finally, a numerical example is given to illustrate the performance of this model. The results show that the optimal preventive maintenance threshold obtained from the proposed decision model can satisfy the spare parts support requirements under (S-1,S) inventory control strategy.
\end{abstract}

Keywords: spare parts, inventory control, ordering, condition based maintenance, Monte-Carlo simulation.

\begin{abstract}
Dążąc do jednoczesnej optymalizacji utrzymania ruchu urządzeń i zarządzania zamówieniami części zamiennych, zaproponowano kompleksowy model decyzyjny w ramach strategii utrzymania zależnej od bieżącego stanu technicznego (CBM) przeznaczony dla systemów z pojedynczym urządzeniem i ciagłym oraz losowym zużyciem. W niniejszym modelu, zużycie urzadzenia jest ciagłym procesem Gamma z ciagłym monitorowaniem stanu, podczas gdy zapasy części zamiennych sa kontrolowane poprzez prawdopodobieństwo wsparcia $w$ zakresie części zamiennych. Po pierwsze, opracowano model prawdopodobieństwa wsparcia w zakresie części zamiennych $w$ celu określenia optymalnego poziomu zapasów części zamiennych $S$, ustalonej aby spetnić wymogi określonego prawdopodobieństwa braku dostępności. Po drugie, przeprowadzono proces decyzyjny dotyczacy wymiany urzadzenia i zamawiania części zamiennych w celu jednoczesnej optymalizacji wymiany urządzenia i zamawiania części zamiennych, w oparciu o poziom zużycia urzadzenia i catkowity koszt działania systemu. Po trzecie, zaprezentowano zintegrowany symulacyjny model decyzyjny dla oceny poziomu kosztów, dostępności i prawdopodobieństwa jej braku. Zasady niniejszego modelu zilustrowano przyktadem numerycznym. Wyniki pokazuja, że optymalny próg konserwacji zapobiegawczej uzyskany za pomoca proponowanego modelu decyzyjnego może spetnić wymagania dotyczace części zamiennych w ramach $(S-1, S)$ strategii kontroli zapasów.
\end{abstract}

Stowa kluczowe: części zamienne, kontrola zapasów, zamówienia, utrzymanie zależne od bieżącego stanu technicznego, symulacja Monte Carlo.

\section{Introduction}

Condition based maintenance (CBM), as one of the most important maintenance method, has been studied extensively in recent years. Based on the analysis of fault mechanism and the test results without disassembly repairing, decision of repair or replace can be made and functional failures can be avoid to a large extend. The advantage of $\mathrm{CBM}$ is to supervisory control the working states detect the problems and take corresponding measures in time. It can make an effective prevention before some failures occur, even some serious failures can be prevented or excluded. As a result, it can prevent the occurrence of serious fault, greatly reduce the failure rate and repair costs, improve the usability of equipment, and change the maintenance work from passive to active.
Since the 1990s, research reports on CBM modeling and optimization are growing constantly. Using the CBM, engineers can make a maintenance decision on the basis of equipment deterioration level and the health status from the equipment condition monitoring data. In the current engineering practice, the decision criteria of CBM are mostly based on the engineer's experience or supplier's recommendations. However, the working environments and workloads in different companies are different, and therefore the rationality and scientificity of these decisions criteria has been questioned by researchers. Condition based maintenance modeling and optimization techniques have been studied widely [17]. Grall et al. [2, 5, 6] have studied a class of single equipment system, which is modeled as a continuous deterioration and stochastic process, with a state implementation by non-periodic inspection, and establish an appropriate analytical model. However, these 
studies did not take into account the availability of repair spare parts. Dohi et al. [3] proposed an ordering and changing strategy for single equipment system. The decisions on spare parts ordering and system replacement are based on the time. Among them, the delivery time of normal order and emergency orders is a random variable which obeys different distributions. Sheu and Griffith [14] proposed an age replacement policy. In which, the maintenance work includes minor maintenance, and the delivery time of spare parts ordering is random. Sheu et al. [15] studied the age replacement policy like document [14] for single equipment system, which includes impact deterioration system. Alenka [1] studied the joint optimization problem of periodic batch replacement and periodic spare procurement. These studies have only considered the spare parts ordering strategy under planned maintenance system and based on spare parts inventory levels. While the research on joint optimization of spare parts ordering and equipment replacement under CBM strategy is rarely at present. Yoo et al. [19] presented an expected cost model which formulated for the joint spare stocking and block replacement policy using the renewal process. Kawai [7, 8] discussed a decision optimization problem on spare parts ordering and equipment replacement for a Markov degradation system. In which, the decision on spare parts ordering or equipment replacement was given based on the deteriorating state of the system. Y. B. Wang et al. [18] discussed spare parts allocation optimization in a multi-echelon support system based on multi-objective particle swarm optimization method. In fact, most of the degradation process of system is continuous, and the system modeling by the application of Markov chain will make the degradation states divided into several intervals for the discrete random process. In addition, the state transition matrix estimation is often more difficult, which characterizes the discrete time in Markov chain.

In this paper, the problem of maintenance strategy is considered for a single equipment system which shutdown will cause more losses, or even lead to disastrous consequences. Therefore, it is necessary to make a preventive replacement of equipment before failure. When the deterioration of the working unit reaches a scheduled preventive maintenance threshold, a prevention replacement will be conducted using spare parts. In view of the continuous monitoring on a single equipment system, this paper will develop a strategy of equipment replacement and spare parts ordering under condition based maintenance. Under this strategy, the replacement action and spare parts inventory control is driven by the unit deterioration. Spare parts inventory control strategy is $(S, S-1)$, and spare parts support meets the given stockout probability.

The rest of this paper is arranged as follows. In section 2, the system description is presented, which includes the analysis of degradation processes and the modeling assumptions. Section 3 describes the development of the spare parts inventory control model. In which, a spare parts support probability model is established to ensure the optimum stock of spare parts S. Then, the equipment maintenance and spare parts ordering model is presented. In section 4, an integrated decision models for equipment maintenance and spare parts inventory is developed. Section 5 gives an example to show the performance of the proposed model. Finally, in section 6, conclusions are drawn from the work.

\section{Description of the system}

\subsection{Notations}

In order to establish the comprehensive decision model, the main parameters are defined as follows:

$F_{\alpha, \beta}(t)$ fault cumulative distribution function of the equipment, where $\alpha$ is the shape parameter, and $\beta$ is the scale parameter.
$L \quad$ order delivery time, which is a random variable.

$g(l) \quad$ the probability density distribution function of order delivery time.

$c_{f}$ the costs per breakdown maintenance, which is assumed to be constant value.

$c_{p m} \quad$ the cost per preventive maintenance.

$c_{q} \quad$ the loss for equipment unit downtime.

$c_{o} \quad$ the management cost of the unit spare parts.

$M_{f} \quad$ time of each breakdown maintenance, is assumed to be constant value.

$M_{p m} \quad$ time of each preventive maintenance.

$T \quad$ time of a working cycle.

$\omega \quad$ stockout probability of spare parts.

$\eta \quad$ the maximum allowable stockout probability.

$\xi_{D_{p m}} \quad$ total number of the arrival of spare parts in the cycle $[0, T]$.

$S C L$ total number of the stockout of spare parts in the cycle $[0, T]$

$N_{D_{p m}} \quad$ total times of the maintenance in the cycle $[0, T]$, which is the sum of spare parts orders.

$E\left[N_{D_{p m}}\right]$ expected number of the replacement in the cycle $[0, T]$

$S^{*} \quad$ optimum inventory number of spare parts.

$t_{k}$ arrival time for spare parts $k$, $k \in\left[S^{*}+1, S^{*}+2, \cdots, \xi_{p m}\right]$

$I_{k} \quad$ the existing inventory levels after the kth times of preventive maintenance $k \in\left[1,2, \cdots, N_{p m}\right]$.

$D_{p m} \quad$ preventive maintenance threshold.

$D_{f} \quad$ failure threshold of the degradation.

$T_{D_{p m}}^{(k)} \quad$ working time of the kth components, $k \in\left[1,2, \cdots, N_{p m}\right]$

$T_{\text {cum }}^{(k)} \quad$ system working time when the kth components has been under preventive maintenance, $k \in\left[1,2, \cdots, N_{p m}\right]$

$E\left[C_{m}\right] \quad$ expected costs of equipment maintenance and replacement in the cycle $[0, T]$.

$E\left[C_{q}\right] \quad$ expected cost of downtime loss in the cycle $[0, T]$.

$E\left[C_{o}\right] \quad$ expected cost of spare parts management in the cycle $[0, T]$.

$E[C]$ expected cost of equipment total operating in the cycle $[0, T]$.

$D(T) \quad$ average downtime of equipment in the cycle $[0, T]$.

$A(T) \quad$ average availability of equipment in the cycle $[0, T]$. 


\subsection{Degradation processes analysis}

Generally, there are many kinds of distributions for equipment deterioration. However, Gamma distribution has a strong universality for the traditional exponential, Chi-square and Erlang distribution are all the special cases of the Gamma distribution [4]. Therefore, Gamma distribution is suitable for various forms of distribution. It can be used to represent different failure distributions such as the early failure, occasional failure and exhaustion failure. Therefore, we take Gamma distribution as the form of equipment deterioration in this paper.

The status parameters of equipment is characterized by the random variable $D\left(t_{i}\right)$ at time $t_{i}$, where $t_{1}<t_{2}<\cdots<t_{n}, t_{i} \in T_{h}, 1 \leq i \leq n$. If theincremental $D\left(t_{1}\right), D\left(t_{2}\right)-D\left(t_{1}\right), D\left(t_{3}\right)-D\left(t_{2}\right), \ldots, D\left(t_{n}\right)-D\left(t_{n-1}\right)$ are independent of each other, $\left\{D(t), t \in T_{h}\right\}$ is called independent increment process [11]. If the distribution of $D(t)-D(s)$ is only rely on $t-s$ for all $0 \leq s \leq t$, we can say that $\left\{D(t), t \in T_{h}\right\}$ have a stationary increment. The independent increment processes with stationary increments is called stationary and independent increment process.

The Gamma process is time-homogeneous Lévya process, which is a kind of random and continuous process with independent incre-

ments [16]. A standard Gamma process $\left\{\gamma_{t}, t \in T_{h}\right\}$ has a stable, independent and nonnegative increment. If the incremental degradation

was expressed as $D(i)=D\left(t_{i}\right)-D\left(t_{i-1}\right)$ in time $\left[t_{i-1}, t_{i}\right]$, the Gamma process has the following properties:

(a) $D(i)$ is a smooth, independence and nonnegative increment.

(b) $D(i)$ obeys a distribution with probability density of $\operatorname{gamma}\left(\alpha\left(t_{i}-t_{i-1}\right), \beta\right)$, where $\alpha$ is the shape parameter, $\beta$ is the scale parameter, that is:

$$
D(i) \sim \frac{d_{i}^{\alpha\left(t_{i}-t_{i-1}\right)-1} \exp \left(-\beta d_{i}\right) \beta^{\alpha\left(t_{i}-t_{i-1}\right)}}{\Gamma\left(\alpha\left(t_{i}-t_{i-1}\right)\right)} .
$$

The cumulative failure distribution function of Gamma process can be expressed as:

$$
F_{\alpha, \beta}(t)=\operatorname{Pr}(X<t)=\operatorname{Pr}\left(D(t)>D_{f}\right),
$$

where, $X$ is the life of the product, $D_{f}$ is the failure threshold.

The deterioration process of equipment is a continuous Gamma process, and the cumulative failure distribution function is:

$$
F_{\alpha, \beta}(t)=\frac{\Gamma\left(\alpha t, \beta\left(D_{f}-x_{0}\right)\right)}{\Gamma(\alpha t)},
$$

where $\alpha$ is the shape parameter, $\beta$ is the scale parameter, $x_{0}$ means the state parameters of the initial moment.

Park and Padgett [13] gave the Gamma function degradation process, which includes degradation time and amount of degradation, and the failure distribution function.

\subsection{General assumptions}

We suppose that the following assumptions are satisfied.

(1) Working period $T$ is always greater than the order delivery time $L$, and $T$ is a fixed value.

(2) The downtime loss is generated by equipment maintenance or lack of spare parts, and it is proportional to the downtime.
(3) Unit spare parts management fee $c_{o}$ includes its own cost, spare parts ordering cost and spare parts storage cost, while $c_{o}$ is a constant.

(4) The stocking spare parts do not deteriorate or fault, and the length of the reserve is not effect to the later working life of spare parts.

(5) The spare parts with earlier ordering must arrive earlier than the later one.

(6) In the integrated decision model, the replacement time is greater than zero, and $D_{p m}$ is less than $D_{f}$. Obviously, when the replacement time is greater than zero, the stockout probability of spare parts will decrease. While the stockout probability of spare parts will be increased when $D_{p m}<D_{f}$. In this paper, it is assumed that the number of the optimal spare parts $S^{*}$ meets the demands of the spare parts support probability in the integrated decision models.

(7) The equipment deterioration is under a continuous condition monitoring. And after preventive maintenance or corrective mantenance, the equipment will resume to a state of "as good as new".

\section{Spare parts inventory control model}

Spare parts support probability represents the probability of demand of equipment spare parts with satisfaction. Its numerical size is closely related to spare parts inventory and spare parts demand.

There are two main kinds of index of spare parts support probability. One is the fill rate, which is the percentage of spare parts meet the needs of supply at any time; the other is the stockout rate. It is the percentage of the requirement quantity of spare parts, which did not meet the supply at some time. Spare parts support probability model is particularly important in some important equipment spare parts support process. Because the safety and economic behavior will cause serious consequences for once the important equipment downtime due to lack of spare parts. For some important equipment spare parts which usually with high prices and very low demand, spare parts inventory control strategy $(S-1, S)$ is the most optimal support scheme $[10,12,13]$. This article will use spare parts support probability model for the spare parts inventory decision.

\subsection{Spare parts support probability models}

A single equipment system under CBM strategy is considered in this paper. The degradation process of equipment is a continuous Gamma process. Its failure probability density function is $f_{\alpha, \beta}(t)$, and the cumulative distribution function is $F_{\alpha, \beta}(t)$. The supply of spare parts inventory control strategy is $(S-1, S)$. The meaning of the inventory policy is that the initial inventory level is $S$, when stocks fall as $S-1$, then a spare part order is request, and the order quantity is $1 . S_{O H}$ is defined as the available inventory of spare parts, $S_{D I}$ is the number of spare parts in transportation, $S_{B O}$ is the number of spare parts for delayed delivery. In the process of the inventory system operation, the relationships among $S_{O H}, S_{D I}, S_{B O}$ and $S$ are as follows:

$$
S=S_{O H}+S_{D I}-S_{B O}
$$

Assuming that preventive maintenance threshold value $D_{p m}$ is equal to the failure threshold value $D_{f}$, and the replacement time is ignored. Under the inventory strategy, when the equipment degrada- 
tion level has reached $D_{f}$, a spare part will be withdraw from the inventory for changing spare parts repair, at the same time, a spare part ordering is performed, and the ordering number is 1 , the ordering delivery time is $L$ (its probability density function is $g(l)$ ). The inventory is out of stock when the equipment degradation reaches to the failure threshold and no inventory for prevent replacement.

Because spare parts ordering delivery time $L>0$, under the condition of meeting the requirement of stockout probability $\eta$, the initial inventory of spare parts quantity $S$ shall meet the following conditions:

$$
\operatorname{Pr}\left(\sum_{i}^{S} T_{i}<L\right)=\int_{0}^{\infty} \operatorname{Pr}\left(S=\sum_{i}^{S} T_{i}<L \mid L=l\right) g(l) d l=\int_{0}^{\infty} g(l) \int_{0}^{l} f_{S}(t) d t d l=\omega \leq \eta,
$$

where, $\omega$ is the stockout probability of spare parts by calculation; $T_{i}$ is the time from using to degradation failure threshold $D_{f}$ for spare parts; $\bar{\varpi}_{S}$ means the sum using time of spare parts, and its probability density distribution function is $f_{\bar{\omega}_{S}}(t)$, the cumulative distribution function is $F_{\bar{\omega}_{S}}(t)$. As the spare parts are of the same type, so the expression of $f_{\bar{\varpi}_{S}}(t)$ is:

$$
F_{S}(t)=F_{\alpha, \beta}^{(S)}(t)=L^{-1}\left\{L\left[F_{\alpha, \beta}(t)\right]^{S}\right\}
$$

where $F_{\alpha, \beta}^{(S)}(t)$ is the dispersed S-fold discrete convolution of $F_{\alpha, \beta}(t), L\left[F_{\alpha, \beta}(t)\right]$ is the Laplace transform for $F_{\alpha, \beta}(t)$, and $S$ represents spare parts inventory quantity. When the spare parts inventory quantity $S$ fit $\omega_{S}<\eta<\omega_{S-1}$, the spare parts inventory quantity is the optimal inventory $\left(S^{*}\right)$.

\subsection{Model solution}

In order to solve the optimal spare parts inventory number to meet the requirements of stockout probability, the spare parts support probability model is established. The Eqs. 5 can be solved by iterative method, and the steps are as follows:

Step 1: Initialize the probability density distribution function $f_{\alpha, \beta}(t)$ of components Gamma degradation process. Then, initialize the failure threshold value $D_{f}$, the probability density distribution function $g(l)$ of order delivery time $L$, the maximum allowable stock-out probability $v$, and make the counter variable $i=1$.

Step 2: Make $S_{i}=i$, and calculate the corresponding stockout probability $\omega_{S_{i}}$.

$\omega_{S_{i}}=\int_{0}^{\infty} g(l) F_{1}(l) d l=E\left[F_{1}(l)\right] \quad \approx \lim _{n \rightarrow \infty} \frac{1}{n} \sum_{i=1}^{n} F_{\alpha, \beta}\left(l_{j}\right) l_{j}=\left\{t \mid G(t)=U_{j}(0,1)\right\}$

in which, $G(\cdot)$ is the cumulative distribution function of the delivery time $L, F_{\alpha, \beta}(\cdot)$ is the Gamma failure cumulative distribution function for spare parts in the process of degradation. If the calculated stockout probability $\omega_{S_{i}}<\eta$, the computation should be end. At this time, $S^{*}=1$, otherwise, the computation should go to the next step.
Step 3: Calculate the Laplace transform for function $f_{\alpha, \beta}(t)$ :

$$
\begin{gathered}
L\left[f_{\alpha, \beta}(t)\right]=\int_{0}^{+\infty} f_{\alpha, \beta}(t) e^{-s t} d t=E\left(e^{-s t}\right) \approx \lim _{n \rightarrow \infty} \frac{1}{n} \sum_{j=1}^{n} e^{-s \tau} j \\
\forall s, \tau_{j}=\left\{t \mid f_{\alpha, \beta}(t)=U_{j}(0,1)\right\} .
\end{gathered}
$$

Step 4: Make $i=i+1, S_{i}=S_{i-1}+1$, and calculate the Laplace transform for function $F_{\bar{\varpi}_{S_{i}}}(t)$ :

$$
L\left[F_{\varpi_{S_{i}}}(t)\right]=\frac{1}{s}\left\{L\left[f_{\alpha, \beta}(t)\right]\right\}^{S_{i}} .
$$

Step 5: Calculate $F_{\varpi_{S_{i}}}(t)=L^{-1}\left\{L\left[F_{\varpi_{S_{i}}}(t)\right]\right\}$.

Step 6: Calculate stockout probability $\omega_{S_{i}}$ when $S_{i}=i$.

$$
\begin{gathered}
\omega_{S_{i}}=\int_{0}^{\infty} g(l) F_{S_{i}}(l) d l=E\left[F_{S_{i}}(l)\right] \quad \approx \lim _{n \rightarrow \infty} \frac{1}{n} \sum_{i=1}^{n} F_{S_{i}}\left(l_{j}\right), \\
l_{j}=\left\{t \mid G(t)=U_{j}(0,1)\right\} .
\end{gathered}
$$

Step 7: If the calculated stockout probability $\omega_{S_{i}}<\eta$, then $S^{*}=i$, and the calculation is end. Otherwise, it should return to step 4.

\section{Integrated decision models for equipment mainte- nance and spare parts inventory}

\subsection{Model description}

In many cases, a system shutdown will cause significant losses, or even lead to disastrous consequences. In order to reduce the risk of shutdown casued by failures, a CBM strategy may be employed. In this paper, it is considered that a system suffers from deteriorating and its condition is monitored under a CBM strategy. Both preventive maintenance and corrective maintenance are involved in the strategy. The role of the preventive maintenance is preventing the replacement before failure. When the deterioration of the work equipment reaches to a predetermined threshold of preventive maintenance, a preventive replacement is implemented by a spare part. Because the equipment deterioration is under a continuous condition monitoring, a corrective maintenance will occur only for spare parts is stockout when the deterioration reaches to the threshold of preventive maintenance. After maintenance, either preventive or corrective, the equipment will restore to a state of "as good as new".

It is supposed that the system is made up of $S+1$ components, in which, one component is working, while the others are as cold redundant. When the working components fault, the redundant parts will replace them one by one. And the spare parts inventory is under $(S-1, S)$ strategy. Which means once preventive replacement (one spare parts needed at one time) is needed when the equipment degrades to the preventive maintenance threshold $D_{p m}$. Then, a spare part ordering is performed. While the order number is 1 , and order delivery time $L$ is a random variable. Here, the redundant components $S$ must fulfill that its stockout probability is less than $\eta$ within the order delivery time $L$. The aim of constructing this model is to solve 
the optimal $D_{p m}$ with a minimum cost of system total operation, which is based on calculation of $S$ under the prescribed conditions.

\subsection{Model construction}

Under the CBM strategy, the maintenance decision-making and spare parts ordering are performed based on the equipment degradation and inventory levels in this paper. In addition, the spare parts inventory level is affected by the spare parts order delivery time and the replacement of the equipment. As a result, it is difficult to establish a mathematical model to calculate the system costs. So, a simulation model is used to simulate the system maintenance cycle such as replacement, spare parts ordering and inventory in this paper. And the related fee is estimated through Monte-Carlo simulation method.

\subsubsection{Equipment maintenance and spare parts ordering}

In one work cycle $[0, T]$, the analysis of equipment maintenance and spare parts inventory are as follows:

(1) Equipment maintenance analysis

- When $0<T<T_{\text {cum }}^{(1)}$, equipment does not need maintenance.

- When $0<T_{\text {cum }}^{(k)}<T$ and $T_{\text {cum }}^{(k)}+M_{p m}<T$, if the inventory of spare parts is not zero, equipment preventive maintenance is performed one time; if the inventory of spare parts is zero, then the equipment will be down for lack of spare parts. And the equipment preventive maintenance should be performed after the ordering spare parts arrival.

- When $0<T_{\text {cum }}^{(k)}<T$ and $T_{\text {cum }}^{(k)}+M_{p m}>T$, equipment does not need maintenance.

(2) Spare parts inventory analysis

-When a spare part requirement is generated, if the inventory level $I>0$, then $I$ reduce 1 , and maintenance times $N_{D_{p m}}$ increase 1 . If the inventory level is zero, the stockout number $S C L$ increase 1.

- When the ordering spare parts arrival to the warehouse, the number of the arrival spare parts increase 1, and the total number of existing inventory $I$ increase 1 .

\subsubsection{The cost ratio}

The total operating cost of the equipment consists of the following three parts: the costs of equipment maintenance and replacement, the downtime costs, and the costs of spare parts management.

The expected costs of maintenance and replacement in the cycle $[0, T]$ can be expressed by:

$$
E\left[C_{m}\right]=c_{p m} E\left[N_{D_{p m}}\right] .
$$

The expected cost of downtime loss in the cycle $[0, T]$ can be given by:

$$
E\left[C_{q}\right]=c_{q}\left(T-\sum_{k=1}^{N_{D_{p m}}} T_{D_{p m}}^{(k)}\right) .
$$

The expected cost of spare parts management in the cycle $[0, T]$ can be expressed as following:

$$
E\left[C_{o}\right]=c_{o} E\left[N_{D_{p m}}\right]
$$

Then, the expected total cost $E[C]$ for the equipment operating in the cycle $[0, T]$ can be expressed by:

$$
\begin{aligned}
& E[C]=E\left[C_{m}\right]+E\left[C_{q}\right]+E\left[C_{o}\right] \\
& \quad=c_{p m} E\left[N_{D_{p m}}\right] \quad+c_{q}\left(T-\sum_{k=1}^{N_{D_{p m}}} T_{D_{p m}}^{(k)}\right)+c_{o} E\left[N_{D_{p m}}\right]
\end{aligned}
$$

Then, the model can be obtained as follows:

(1) The objective function is:

$$
\min _{D_{p m}} E\left(c_{p m} E\left[N_{D_{p m}}\right]+c_{q}\left(T-\sum_{k=1}^{N_{D_{p m}}} T_{D_{p m}}^{(k)}\right)+c_{o} E\left[N_{D_{p m}}\right]\right) .
$$

(2) The constraint conditions include:

$$
\left\{\begin{aligned}
& N_{D_{p m}}=\sup \{ i\left[\left(\sum_{k=1}^{i} T_{D_{p m}}^{(k)}+\sum_{k=1}^{i} M_{p m}+\sum_{k=S^{*}+1}^{i} \varphi_{k}\right) \leq T\right\} \\
& E\left[\frac{\sum_{k=S^{*}+1}^{\xi \cdot D_{p m}} \partial_{k}}{\xi D_{p m}}\right] \leq \eta
\end{aligned}\right.
$$

where $\varphi_{k}$ is the time of spares stockout and $\partial_{k}$ means the number of spares stockout. The expressions for them are as follows respectively:

$$
\varphi_{k}=\left\{\begin{array}{rr}
\inf \left\{t_{k} \mid t_{k} \geq T_{\text {cum }}^{(k)}\right\}-T_{\text {cum }}^{(k)} & \text { if } \quad I_{k}=0 \\
\forall k \in\left[S^{*}+1, S^{*}+3, \ldots, N_{D_{p m}}\right] \\
0 & \text { otherwise }
\end{array}\right.
$$

$$
\partial_{k}=\left\{\begin{array}{ll}
1 & \text { if } \quad t_{k}>S^{*} E\left(T_{p m}\right) \\
0 & \text { otherwise }
\end{array} .\right.
$$

\subsubsection{Availability}

If the average downtime in the working cycle $[0, T]$ can be acquired, the equipment availability can be calculated by:

$$
A(T)=\frac{T-D(T)}{T}
$$

Because the equipment downtime includes maintenance time and stockout time, so the expression of average downtime in a work cycle $[0, T]$ is expressed as:

$$
D(T)=E\left[\sum_{k=1}^{N_{D_{p m}}} M_{p m}+\sum_{k=S^{*}+1}^{N_{D_{p m}}} \varphi_{k}\right] .
$$




\subsection{Model solution}

In order to obtain the optimal preventive maintenance threshold, the smallest operating costs of the system and the systems availability, a Monte Carlo simulation and iterative optimization program flow for the ordering and replacement policy is given as follows:

Step 1: Parameter initialization, that is the system parameters such as $\alpha, \beta, D_{f}, c_{f}, c_{b}, c_{o}, M_{f}$, and $T$ should be entered into. Then, let $T_{0}^{\prime}=0, I_{0}=S, N_{D_{p m}}=0, \xi_{D_{p m}}=0, S C L=0$. In which, $T_{i}^{\prime}$ means the starting point of the work time for the $i$ th spare parts; $T_{j}$ means the arrival time for the $j$ th spare parts ordering; $I_{i}$ means the existing inventory number after the $i$ th maintenance and replacement; SCL means the stockout number of the spare parts.

Step 2: Let $k=1, D_{p m}=D_{f}-k \Delta D$, where $\Delta D$ is the unit deterioration amount. For a certain $D_{p m}$, we can use the corresponding generated random numbers to simulate a work cycle of the equipment maintenance and replacement and the inventory cycle. Then, the maintenance replacement times $N_{D_{p m}}$, equipment working time $\sum_{k=1}^{N_{D_{p m}}} T_{D_{p m}}^{(k)}$, the arrival spare parts numbers $\xi_{D_{p m}}$, and the stockout number of the spare parts $S C L$ can be acquired. This simulation process is repeated $N$ times, while $N$ should be set large enough.

Step 3: Make $k=k+1$, if $D_{p m}>\Delta D$, it should return to step 2 . Else, it will continue with the next step.

Step 4: For a certain $D_{p m}$, the values such as the expected maintenance times $E\left[N_{D_{p m}}\right]$, working time $E\left[\sum_{k=1}^{N_{D_{p m}}} T_{D_{p m}}^{(k)}\right]$, arrival spare parts number $E\left[\xi_{D_{p m}}\right]$, and the stockout number $E[S C L]$ can be calculated within $N$ times simulation during the working cycle $[0, T]$. Accordingly, the systems total running fee, spare parts stockout probability, and system's availability can be worked out. Finally, the optimal threshold value of preventive maintenance can be acquired by decision on the calculated results above.

\section{Example analysis}

In order to explain the equipment maintenance and spare parts ordering of the integrated decision model, the following numerical example is given. The assignment model parameters are shown in table 1 .

In the example, it is assumed that the more serious the equipment deteriorates, the longer the time spent in preventive maintenance. In addition, the equipment maintenance time consuming is increased exponentially with the degree of equipment deterioration [9]. That is:

$$
M_{p m}=M_{f} \exp \left(1-\frac{D_{f}}{D_{p m}}\right)
$$

Similarly, it is assumed that the more serious the equipment deteriorate, the more costs will spend for preventive maintenance. In addition, the equipment maintenance and replacement cost consuming
Table 1. Model parameter values

\begin{tabular}{||c|c|c|}
\hline $\begin{array}{c}\text { Model } \\
\text { vari- } \\
\text { able }\end{array}$ & Values & Variables description \\
\hline$\alpha$ & 0.7 & $\begin{array}{c}\text { shape parameter of Gamma deterioration } \\
\text { process function }\end{array}$ \\
\hline$\beta$ & 0.006 & $\begin{array}{c}\text { scale parameter of Gamma deterioration proc- } \\
\text { ess function }\end{array}$ \\
\hline$D_{f}$ & 45 & failure threshold \\
\hline$\eta$ & 0.1 & the maximum allowed stockout probability \\
\hline$g(l)$ & $\begin{array}{c}\text { Logn }(0.02, \\
0.05)\end{array}$ & $\begin{array}{c}\text { probability density function of L (as lognormal } \\
\text { distribution) }\end{array}$ \\
\hline$c_{f}$ & 1500 & maintenance costs for each fault \\
\hline$c_{q}$ & 3750 & downtime loss in unit time \\
\hline$c_{o}$ & 1200 & management fee for unit spare parts \\
\hline$M_{f}$ & 0.4 & maintenance time for each fault \\
\hline$T$ & 10 & time of a work cycle \\
\hline \hline
\end{tabular}

is increased exponentially with the degree of equipment deterioration. It can be expressed as follows:

$$
c_{p m}=c_{f} \exp \left(1-\frac{D_{f}}{D_{p m}}\right)
$$

(1) Spare parts inventory decision

According to the data in table 1 , the optimal spare parts inventory level $S^{*}$ can be worked out by the iterative method offered by this paper. The iterative results are shown in Table 2.

Table 2. The iterative results from the model

\begin{tabular}{|c|c|}
\hline \hline Inventory level & Probability of stockout \\
\hline 1 & 0.6132 \\
\hline 2 & 0.2119 \\
\hline $3^{*}$ & 0.0563 \\
\hline
\end{tabular}

From Table 2, it can be seen that $\omega_{3}<\eta<\omega_{2}$. That is when the inventory level $S=3$, the system probability of stockout can meet the stated probability. So, the optimal spare parts inventory level $S^{*}=3$.

(2) Preventive maintenance threshold decision

When the optimal inventory level of spare parts $S^{*}$ is certain, the model can be commutated by the Monte-Carlo simulation and iterative methods mentioned above. According to the parameters in Table 1 , and make $D_{p m}$ as $40,39, \ldots, 6,5$, with 1000 times simulation, we can acquire the results of the integrated decision model, which is shown in Table 3.

The optimization results of simulation and iterative can be seen from Table 3. When $D_{p m}=13$, the system total operation cost is minimum, and the spare parts stockout probability $\omega$ is less than the maximum allowable value. However, the system availability is not optimal when $D_{p m}=13$, and the system availability is optimal when 
Table3. Results of the integrated model

\begin{tabular}{|c|c|c|c|}
\hline$D_{p m}$ & $E[C]$ & $\omega$ & $A(T)$ \\
\hline 5 & 30880.44 & 0.21618 & 0.88239 \\
\hline 6 & 29607.95 & 0.198461 & 0.894771 \\
\hline 7 & 28561.55 & 0.18244 & 0.90516 \\
\hline 8 & 27970.29 & 0.169532 & 0.909784 \\
\hline 9 & 27336.67 & 0.153453 & 0.914717 \\
\hline 10 & 26839.91 & 0.13803 & 0.918041 \\
\hline 11 & 26675.81 & 0.124363 & 0.91676 \\
\hline 12 & 26624.36 & 0.109821 & 0.914296 \\
\hline 13 & $26607.64^{* *}$ & 0.095687 & 0.910787 \\
\hline 14 & 26705.73 & 0.082576 & 0.90459 \\
\hline 15 & 26874.62 & 0.07073 & 0.897384 \\
\hline 16 & 27101.41 & 0.058625 & 0.88962 \\
\hline 17 & 27527.31 & 0.047001 & 0.880479 \\
\hline 18 & 27619.84 & 0.036678 & 0.87244 \\
\hline 19 & 27972.22 & 0.028778 & 0.862553 \\
\hline 20 & 28337.86 & 0.022847 & 0.852379 \\
\hline 21 & 28675.48 & 0.016327 & 0.842734 \\
\hline 22 & 28984.62 & 0.011862 & 0.83295 \\
\hline 23 & 29216.69 & 0.007853 & 0.824186 \\
\hline 24 & 29601.3 & 0.005604 & 0.814682 \\
\hline 25 & 29908.11 & 0.00338 & 0.805714 \\
\hline 26 & 30196.85 & 0.001949 & 0.797351 \\
\hline 27 & 30356.97 & 0.000976 & 0.790473 \\
\hline 28 & 30553.85 & 0.000357 & 0.783137 \\
\hline 29 & 30800.67 & 0.000144 & 0.776247 \\
\hline 30 & 31108.70 & 0 & 0.769122 \\
\hline 31 & 31373.56 & 0 & 0.761944 \\
\hline 32 & 31451.68 & 0 & 0.756873 \\
\hline 33 & 31639.67 & 0 & 0.751418 \\
\hline 34 & 31721.76 & 0 & 0.747231 \\
\hline 35 & 32027.27 & 0 & 0.74094 \\
\hline 36 & 32026.95 & 0 & 0.737948 \\
\hline 37 & 32081.98 & 0 & 0.734462 \\
\hline 38 & 32226.08 & 0 & 0.729654 \\
\hline 39 & 32434.29 & 0 & 0.725858 \\
\hline 40 & 32392.65 & 0 & 0.722997 \\
\hline
\end{tabular}

$D_{p m}=10$. This shows that the total operation cost and availability of this system cannot achieve optimal at the same time.

In order to analyses the simulation data more intuitively to make a maintenance decision, Three figures are drawn according to the simulation data, which is shown as Figure 1, Figure 2 and Figure 3.

Fig. 1 shows the relationship between the total operating costs $C$, maintenance costs $C_{m}$, cost of downtime loss $C_{q}$, costs of spare parts management $C_{o}$ and preventive maintenance threshold value $D_{p m}$.

From Fig.1, It can be seen that: (1) there is an optimum preventive maintenance threshold with a minimum costs for total operating; (2) the maintenance costs is increased with the increasing of $D_{p m}$, which is related to the model assumption that the more serious the equipment deteriorate, the more costs will spend for preventive mainte-

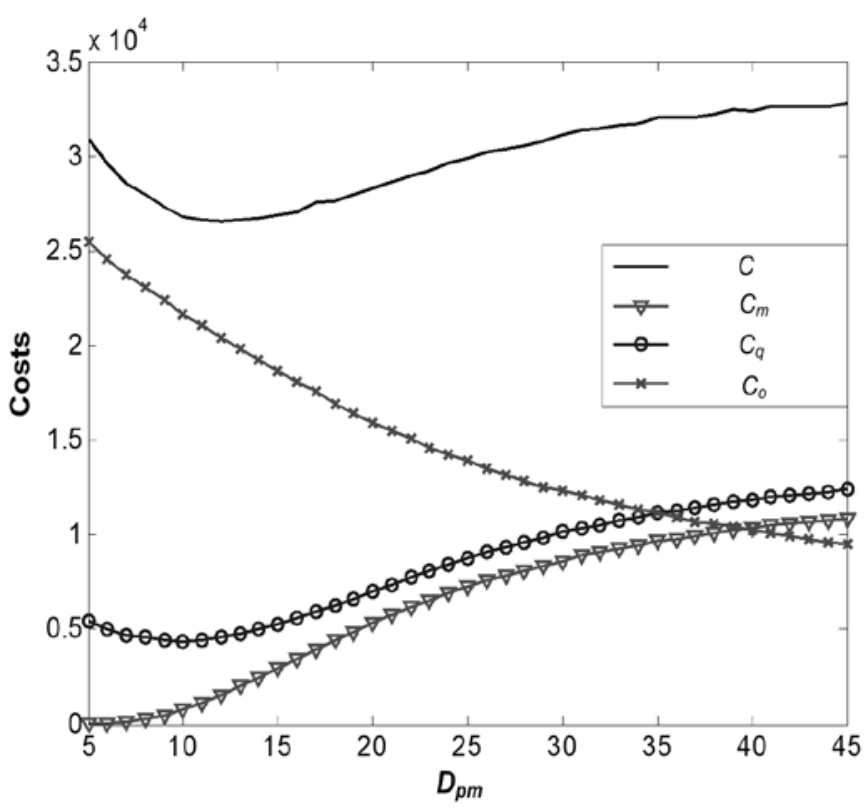

Fig. 1. The corresponding relationship of costs and $D_{p m}$

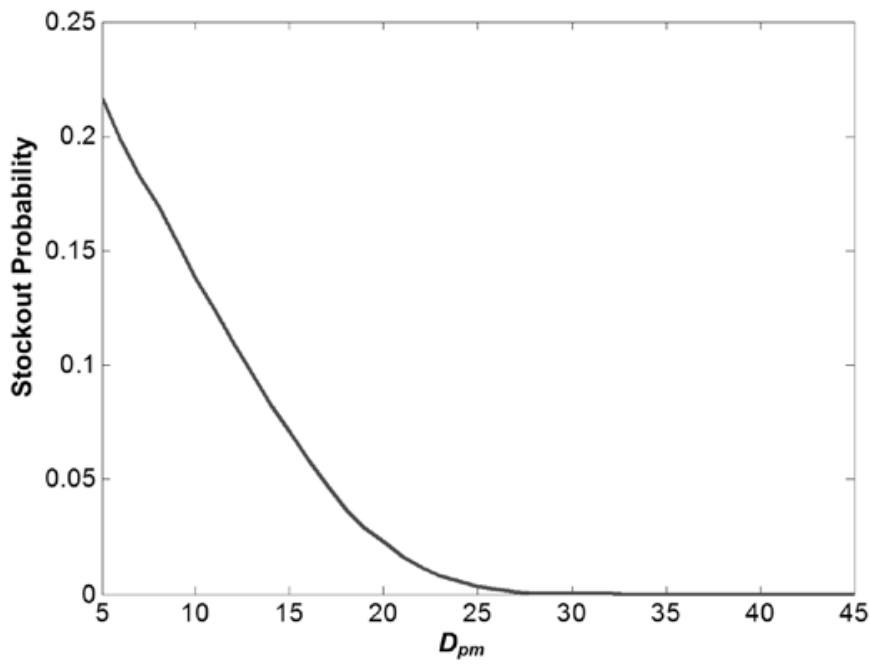

Fig. 2. The corresponding relationship of stockout probability and $D_{p m}$

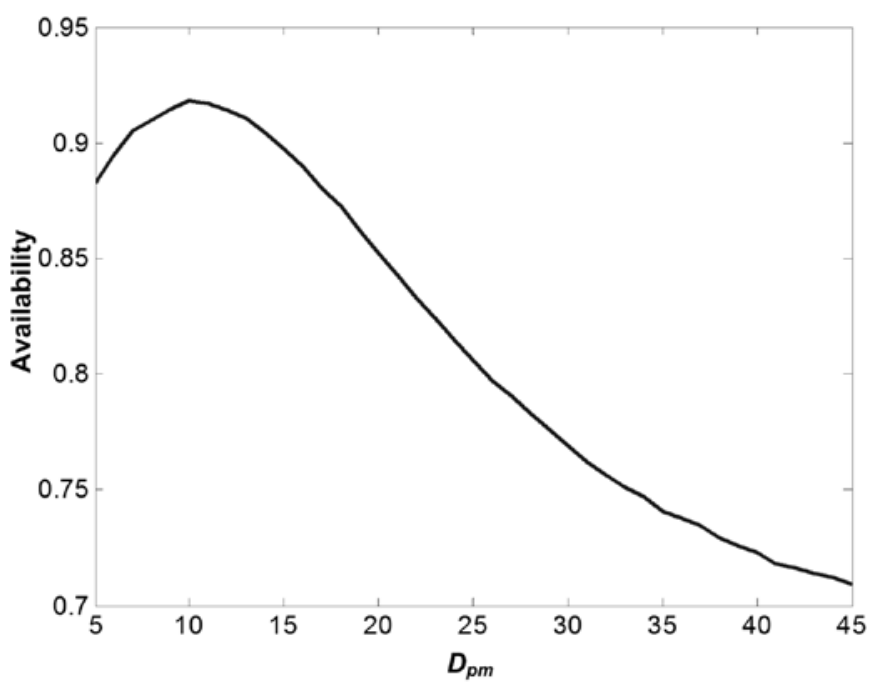

Fig. 3. The corresponding relationship of availability and $D_{p m}$ 
nance; (3) there is a firstly drop and later increase process for the costs of downtime loss with the increasing of $D_{p m}$, which is related to the stockout time increases rapidly when threshold value is too small and the maintenance time increases rapidly when preventive maintenance threshold is too large; (4) the cost of spare parts management is gradually reduced with the increasing of $D_{p m}$, which is related to that the longer the single equipment working, the less the maintenance times in need during the working cycle.

Fig.2 shows the relationship of the $a$ and $D_{p m}$ when the maximum number of stock $\mathrm{S}$ is determined. It can be seen from Fig.2 that the bigger the $D_{p m}$, the smaller the $\omega$. The reason is that the longer single equipment work, the smaller the stockout probability of the system.

Fig. 3 shows the relationship of the system availability and $D_{p m}$. It can be seen from Fig. 3 that the equipment availability is increased with the increasing of $D_{p m}$ at first. When it reaches to a certain value, it will decrease with the increasing of $D_{p m}$ afterwards. It because the maintenance frequency will increase when $D_{p m}$ is too small, and the equipment downtime will increase for the lack of spare parts. While the maintenance time will increase when the $D_{p m}$ is too large, and the equipment availability will decrease correspondingly.

\section{Conclusions}

In this paper, a spare parts inventory control and integrated decision model is proposed based on the CBM for a class of single equipment system. Firstly, the spare parts support probability model is established to determine the optimum stock of spare parts. And then the system operation and spare parts ordering comprehensive decision-making simulation model is established, which can be used to calculate the running fee rate, system availability and the stockout probability of spare parts. At last, the model is verified by a numerical example. The results show that the optimal preventive maintenance threshold $D_{p m}$ with the decision of target of cost can meet the requirements of spare parts support degree under the $(S-1, S)$ strategy. However, the fee rate and availability cannot achieve an optimal point at the same time.

It is noted that although a Gamma deterioration process is used to develop the spare parts control model, the proposed model may allow other types of distriburion to be incorporated to obtain an optimal stragety for spares controling.

\section{References}

1. Alenka B. Alenka. Joint optimization of block-replacement and periodic-review spare-provisioning policy. IEEE Transactions on Reliability 2003; 52(1): 112-117, http://dx.doi.org/10.1109/TR.2002.805790.

2. Dieulle L. Sequential condition-based maintenance scheduling for a deteriorating system. European Journal of Operational Research 2003; 150: 451-461, http://dx.doi.org/10.1016/S0377-2217(02)00593-3.

3. Dohi T. On the optimal ordering policies in maintenance theory: survey and applications. Applied Stochastic Models and Data Analysis 1998; 20(14): 309-321, http://dx.doi.org/10.1002/(SICI)1099-0747(199812)14:4<309::AID-ASM351>3.0.CO;2-R.

4. Gamma distribution [Online].Available: http: // www.brightonwebs.co.uk / distributions / Gamma.asp.

5. Grall A. A condition-based maintenance policy for stochastically deteriorating systems. Reliability Engineering and System Safety 2002; 76: 167-180, http://dx.doi.org/10.1016/S0951-8320(01)00148-X.

6. Grall A. Continuous time predictive maintenance scheduling for a deteriorating system. IEEE Transaction on Reliability 2002; 51: 141-150, http://dx.doi.org/10.1109/TR.2002.1011518.

7. Kawai H. An optimal ordering and replacement policy of a Markovian degradation system under complete observation: part I. Journal of the Operational Research Society of Japan 1983; 26(4): 279-291.

8. Kawai H. An optimal ordering and replacement policy of a Markovian degradation system under complete observation: part II. Journal of the Operational Research Society of Japan 1983; 26(4): 293-307.

9. Liao H T. Maintenance of continuously monitored degrading systems. European Journal of Operational Research 2006; 175: 821-835, http:// dx.doi.org/10.1016/j.ejor.2005.05.017.

10. Liu Y, Huang H Z. Optimal replacement policy for multi-state system under imperfect maintenance. IEEE Transactions on Reliability 2010; 59(3): 483-495, http://dx.doi.org/10.1109/TR.2010.2051242.

11. Lin Y L. Application of random process. Beijing, China, Tsinghua university press, pp. 20-30, 2002.

12. Oner K B. Optimization of component reliability in the design phase of capital goods. European Journal of Operational Research 2010; 205(3): 615-624, http://dx.doi.org/10.1016/j.ejor.2010.01.030.

13. Park C. Padgett. Accelerated degradation models for failure based on geometric brownian motion and Gamma process. Life-time Data Analysis 2005; 11: 511-527, http://dx.doi.org/10.1007/s10985-005-5237-8.

14. Sheu S H. Griffith. Optimal age-replacement policy with age-dependent minimal-repair and random lead-time. IEEE Transaction on Reliability 2001; 50: 302-309, http://dx.doi.org/10.1109/24.974128.

15. Sheu S H. Chien. Optimal age-replacement policy of a system subject to shocks with random lead-time. European Journal of Operational Research 2004; 159: 132-144, http://dx.doi.org/10.1016/S0377-2217(03)00409-0.

16. Wang C H. Statistical inference for the process of generalized Gamma. Journal of East China University of Science and Technology (Natural Science Edition) 1995; 21(3): 392-399.

17. Wang L. Theory and application of maintenance decision models and methods. PhD thesis of Zhejiang University, 2007.

18. Wang Y B. Spare parts allocation optimization in a multi-echelon support system based on multi-objective particle swarm optimization method. Ekslpoatacja i Niezawodnosc - Maintenance and Reliability 2014; 16(1): 29-36.

19. Yoo Y K. Optimal joint spare stocking and block replacement policy. International Journal of Advance Manufacture Technology 2001; 18: 906-909, http://dx.doi.org/10.1007/PL00003959. 


\section{Yabin WANG}

Jianmin ZHAO

\section{Zhonghua CHENG}

\section{Zhiyuan YANG}

Department of Management Engineering

Mechanical Engineering College

Shijiazhuang 050003, P. R. China

E-mail:wangyabin123@163.com,jm_zhao@hotmail.com, zszs197466@163.com,yzy_sjz90@126.com 